This is the accepted version of an article published by Cambridge in The Journal of Modern African Studies Vol. 53 No. 1, pp. 27-49, 2017. Published version available from: https://doi.org/10.1017/S0022278X14000640

Accepted version downloaded from SOAS Research Online: https://eprints.soas.ac.uk/26245/

\title{
The battle for Zimbabwe in 2013: from polarisation to ambivalence
}

\author{
JUlia GaLlaGHeR ${ }^{1^{*}}$ \\ Department of Politics and International Relations \\ Royal Holloway, University of London \\ Egham Surrey TW20 0EX \\ julia.gallagher@rhul.ac.uk
}

\begin{abstract}
On the face of it, the triumph of Robert Mugabe and ZANU(PF) in the 2013 elections came as a shock, not least to opposition MDC activists. However, after a period of introspection, many have begun to construct a coherent and wide-ranging account of the result which explores opposition shortcomings, and the revived relationship between the electorate and Mugabe's ZANU(PF). This article, based on interviews with political activists conducted three months after the election, outlines and attempts to explain this account. It explores the way in which a politics of polarisation that dominated Zimbabwe in recent years appears to have given way to a politics of ambivalence: where Zimbabweans once viewed their political landscape as one populated by antinomies, they now see their state and its relation to themselves in more complex and ambiguous ways. As a result, Zimbabweans' conception of the state is
\end{abstract}

\footnotetext{
$1^{*}$ The author would like to thank Teresa Almeida Cravo, Jonathan Fisher, Langton Miriyoga, Stephen Chan and staff and students of the Department of Politics and International Relations at Royal Holloway who provided helpful comments on earlier versions of this article. Thanks also to the extremely constructive suggestions made by the journal's editors and reviewers. Finally, many thanks to the British Academy and Sir Ernest Cassel Educational Trust which provided financial support for the fieldwork carried out in this study.
} 
This is the accepted version of an article published by Cambridge in The Journal of Modern African Studies Vol. 53 No. 1, pp. 27-49, 2017. Published version available from: https://doi.org/10.1017/S0022278X14000640

Accepted version downloaded from SOAS Research Online: https://eprints.soas.ac.uk/26245/

increasingly coming to resemble Mbembe's formulation of states as contemporaneously ‘organizers of public happiness' and wielders of arbitrary violence.

As they happened, Zimbabwe's 2013 elections were difficult to read. The opposition parties argued that Robert Mugabe and his ZANU(PF) party, in power for more than 30 years, increasingly repressive and corrupt, and nearly ousted in 2008 , would be finished by a final push in 2013. They argued that Mugabe's massive and exuberant election rallies, and the ZANU(PF) posters and regalia that festooned the country, covered the real feelings of Zimbabweans who, once alone in the voting booth, would express their real feelings and 'show Mugabe the red card'.

However, the ruling party won a landslide victory taking 61 per cent of the presidential vote and more than two thirds of the parliamentary seats. As one MDC activist in Matabeleland, previously a bastion of MDC support but largely swept by ZANU(PF) in 2013, said:

I still cannot understand how ZANU has taken power. First, in the last 33 years people of this country can tell ZANU(PF) has failed this country in so many ways. Economic meltdown was so obvious... people went away because they could not survive in the country. Second, ZANU had used one ammunition: farm invasion. But those that benefited tended to be destitute. They went into farms but could not farm them. There is no infrastructure around them. All these factors made ZANU very very unpopular. So everyone took for granted that 
This is the accepted version of an article published by Cambridge in The Journal of Modern African Studies Vol. 53 No. 1, pp. 27-49, 2017. Published version available from: https://doi.org/10.1017/S0022278X14000640

Accepted version downloaded from SOAS Research Online: https://eprints.soas.ac.uk/26245/

the MDC would beat them. ${ }^{2}$

The first explanation given has been electoral fraud. Many opposition activists argue that ZANU(PF) bullied, fixed and cheated its way to victory. Although these elections were notable for their peaceful character, they are not thought to have been 'free and fair'. First, the reforms to the security sector, the state-controlled media and the electoral commission - all embedded in the new constitution adopted earlier in the year - were not properly implemented in time for the election. As a result, the parties approached the elections on an uneven playing field. Second, many have suggested that the unspoken threat of violent reprisals, underwritten by memories of the violence of the 2008 elections, intimidated many voters who did not feel free to express their true preference. Finally, the many stories of vote rigging - the obstructions put in the way of voters in MDC strongholds as they tried to register or turned up to vote, the large numbers of 'assisted voters', and stories of busloads of voters being ferried between polling stations and allowed to vote with registration slips even though their names were not on the register - suggest that electoral fraud played a hand in ZANU(PF)'s victory. ${ }^{3}$

There is evidence to back up much of this account, but it has not satisfied close Zimbabwe watchers who have observed that the size of Mugabe's victory points to profound changes in Zimbabwe's political, economic and social structures. Accounts of the election to date - which have dealt with elite-level politics - detail the way in

\footnotetext{
${ }^{2}$ MDC-T activist Bulawayo, 9 November.

${ }^{3}$ On polling irregularities, see the Zimbabwe Election Support Network (ZESN). website:

http://www.zesn.org.zw/index.php/elections-2013 [cited 4 March 2014].
} 
This is the accepted version of an article published by Cambridge in The Journal of Modern African Studies Vol. 53 No. 1, pp. 27-49, 2017. Published version available from: https://doi.org/10.1017/S0022278X14000640

Accepted version downloaded from SOAS Research Online: https://eprints.soas.ac.uk/26245/

which the dynamics of power-sharing between 2009 and 2013 strengthened ZANU(PF) and weakened the MDC (LeBas, 2014), or suggest that structural economic changes have been created and exploited to entrench support for ZANU(PF) (Raftopoulos, 2013). Others have explored the election strategies and performances by the main parties: the MDC's many mistakes (Zamchiya, 2013) and the revived energy and focus of ZANU(PF) (Tendi, 2013).

The aim of this article is to enrich the existing analysis of the 2013 elections by providing an account from the perspectives of grassroots party and civil society activists. Based on interviews conducted three months after the elections, the focus here is on how the campaigns and broader political debates were experienced on the ground, and how those closest to ordinary voters account for the substantial swing in support away from the MDC. From this account, it draws conclusions about how voters understand their relation to the state - both what it is and what they want and expect it to be.

Two contradictory phenomena emerge. The first is that of the constraint on voters, many of whom felt bound, either by physical fear or anxiety at the prospect of material loss, to cast their votes for ZANU(PF). And the second is the prospect of choice that appeared to open up for many of them as they evaluated the different versions offered by the parties of what Zimbabwe was or should be. Taken together, these underline the suspension of the politics of polarisation in Zimbabwe and highlight the emergence of ambivalence towards politics and the state. 
This is the accepted version of an article published by Cambridge in The Journal of Modern African Studies Vol. 53 No. 1, pp. 27-49, 2017. Published version available from: https://doi.org/10.1017/S0022278X14000640

Accepted version downloaded from SOAS Research Online: https://eprints.soas.ac.uk/26245/

Zimbabwean politics has been starkly polarised in recent years. LeBas (2011) has argued that the political parties, and particularly the MDC as it emerged, deliberately highlighted the differences between it and ZANU(PF) as a way to build loyalty and make the idea of shifting allegiance unthinkable to supporters. She details the ways in which polarisation was entrenched through violent confrontation, a mechanism which emphasised the unbridgeable gulf between the parties.

Polarisation was also based on apparently clear-cut ideological differences. The MDC projected itself as a liberal party that prioritised human rights and democracy, and it emphasised its relationships with Western well-wishers. ZANU(PF) meanwhile prioritised a form of nationalism shaped on a repudiation of colonial history, an identification of Zimbabweanness rooted in the land, and articulated in confrontational standoffs with the country's white farmers and the West (NdlovuGatsheni 2009; Tendi, 2010).

For many Zimbabweans, this dichotomy led to a splitting between a bad reality and an idealised good fantasy of statehood (Gallagher, 2013). The bad existing state was represented by ZANU(PF), associated with violence (in episodes such as Gukurahundi in the early 1980s, Murambatsvina in 2005 and election violence in 2005 and 2008), ${ }^{4}$ neglect and mismanagement (most acutely experienced in the hyperinflation period in 2007-8) and the erosion of state institutions (seen in the

\footnotetext{
${ }^{4}$ Gukurahundi was the campaign against a small group of dissidents in Matabeleland in the 1980s during which time 20,000 people were killed or disappeared; Murambatsvina was the operation in poor urban areas of Harare and Bulawayo in which the security forces bulldozed illegal housing. For details on these and on violence during election campaigns, see Sachikonye 2011.
} 
This is the accepted version of an article published by Cambridge in The Journal of Modern African Studies Vol. 53 No. 1, pp. 27-49, 2017. Published version available from: https://doi.org/10.1017/S0022278X14000640

Accepted version downloaded from SOAS Research Online: https://eprints.soas.ac.uk/26245/

decline in education and healthcare services, the increasing corruption of the police force and partisanship of the legal system). The MDC, on the other hand, could be associated with a good state. For many supporters this was evidenced in its battles with and persecution at the hands of the government. For others it was seen in its promotion of human rights and democracy - values that sought both to protect the population from an authoritarian government and embody an ideal rational, developed state.

However, as LeBas argues (2014), the Government of National Unity (GNU), the coalition government inaugurated in the wake of the disputed 2008 elections, whittled away this polarisation. As a partner in government, the MDC lost its ability to mark itself out as antithetical to ZANU(PF), and forfeited the solidity of its hold on its supporters. Moreover, it became clear that many MDC MPs slipped into some of the methods and approaches to government that had once seemed the sole preserve of ZANU(PF), losing touch with constituents and appearing to focus on acquiring material benefits for themselves instead of pursuing national priorities.

As a result, the GNU forced Zimbabweans to reassess their ideas. In particular, it demands the conflation of very different, even contradictory versions of statehood. This phenomenon has been discussed in a number of ways. McGregor, for example, has argued that Zimbabwean civil servants work within both patrimonial and rationalbureaucratic paradigms. She argues that in Zimbabwe, the growth of informal patronage networks are not an alternative to the formal state, but are pursued alongside (albeit in tension with) more rational-legal understandings of institutions (2013: 803). In other words the state is seen in various, often conflicting ways. A 
This is the accepted version of an article published by Cambridge in The Journal of Modern African Studies Vol. 53 No. 1, pp. 27-49, 2017. Published version available from: https://doi.org/10.1017/S0022278X14000640

Accepted version downloaded from SOAS Research Online: https://eprints.soas.ac.uk/26245/

similar theme is pursued by Primorac and Chan in their analysis of Zimbabwean politics as 'hybrid', a politics predicated on the bringing together of a 'willingness to cast away the past with a subtle reiteration of a nationalist indebtedness to it'. Here, they argue, the idea of being either/or becomes less plausible, it is increasingly difficult to take sides' and Zimbabweans have had to confront a state about which they have mixed feelings (2013: 122).

In this article, I explore the degree to which this ambivalence about politics and the state has come to permeate Zimbabwean society. If some rejected the MDC account of statehood, were they choosing instead to opt for Mugabe's patriotic nationalism and patrimonial politics? Or did they, in making the choices they did, reflect an ambivalent approach to the state more in tune with McGregor's tension between politics as 'eating' and politics as 'law, professional delivery services and the general good' (2013: 803) and Primorac and Chan's 'postmodern politics'?

The picture is complicated by the constraints many voters were under. Apart from the misinformation they experienced, exacerbated by ZANU(PF)'s control over the state media, many voters were constrained by fear. As I detail below, memories of the violent reprisals in areas that had voted for the MDC in 2008 guided many voters in rural ZANU(PF) strongholds, and amongst the urban poor. Moreover, as Raftopoulos has argued (2013), the dense and powerful patronage networks that control access to livelihoods in farming, trade and mining, tie people into a dependency on the ruling party. 
This is the accepted version of an article published by Cambridge in The Journal of Modern African Studies Vol. 53 No. 1, pp. 27-49, 2017. Published version available from: https://doi.org/10.1017/S0022278X14000640

Accepted version downloaded from SOAS Research Online: https://eprints.soas.ac.uk/26245/

However, alongside these tangible constraints, the interviews I conducted reveal the choices and opportunities opened up to many voters in 2013. These centre on the kind of state voters felt they wanted, both in terms of the distribution of resources and the form of Zimbabwean identity on offer. Together they establish that Zimbabweans could choose to vote for ZANU(PF), holding together in their minds the knowledge of it as constraining, violent and authoritarian, a sense of its close relation to and understanding of them, and the idea of it as best placed to provide for, contain and embody the country. When people voted for ZANU(PF) they did so with ambivalent feelings rather than a pure sense of the party either as ideal or inevitable.

The rest of the article is in four parts. The first details the background to the election; the second provides a brief discussion of the methodology and dynamics of the interviews conducted; the third outlines the main findings of the research; and the fourth conclusions drawn from them.

\section{BACKGROUND TO ZIMBABWE’S 2013 ELECTION}

The Zimbabwe African National Union Patriotic Front (ZANU(PF)), in power since 1980, faced increasing pressure from a new party - the Movement for Democratic Change (MDC) - which emerged from the trade union movement in 1999 and was led by the charismatic and youthful Morgan Tsvangirai. The MDC was able to articulate opposition to the economic austerity triggered by the country's structural adjustment programme implemented in the early 1990s, and formed a coalition of support from labour, civil society and the urban poor (LeBas 2011: 118). Fast-track land reform, in 
This is the accepted version of an article published by Cambridge in The Journal of Modern African Studies Vol. 53 No. 1, pp. 27-49, 2017. Published version available from: https://doi.org/10.1017/S0022278X14000640

Accepted version downloaded from SOAS Research Online: https://eprints.soas.ac.uk/26245/

which large, white-owned farms were seized and given to black farmers, and a generous compensation package paid to war veterans in 1993, led to further economic decline which drove up support for the MDC. The party gathered support from the middle-class, white farmers and Ndebele and other ethnic and regional groups that had been excluded by the Shona-dominated state (Muzondidya 2009: 184-8). Violence increasingly became a feature of Zimbabwe's politics, expressed in particular by the government towards the urban poor in the Murambatsvina evictions in 2005, and between the parties during elections in 2005 and 2008 (Sachikonye 2011). Violence helped entrench polarisation by heightening political contest into a struggle for physical survival. This helped the MDC pull its disparate support base together, although not entirely successfully as internal pressures led to a split in $2005 .^{5}$

The 2008 election occurred during a period of acute crisis, with hyperinflation at an official level of 230 million per cent (Raftopoulos 2009). The results, delayed for a month, showed dramatic MDC successes: between them, the two MDC parties had won 109 parliamentary seats to ZANU(PF)'s 97, while Tsvangirai had secured $47.9 \%$ in the presidential poll to Mugabe's 43.2\%, thus triggering a run-off. A campaign of violence was unleashed on MDC strongholds, with accounts of beatings, killings, rapes, amputations and large numbers of MDC activists forced to flee (Sachikonye 2011: 45-61). Faced with such an onslaught, Tsvangirai withdrew from the runoff. However, disquiet in the region forced $\mathrm{SADC}^{6}$ leaders to step in and negotiate a

\footnotetext{
${ }^{5}$ Two parties emerged from the split, the much larger MDC-T led by Tsvangirai, and the smaller MDC-M led by Arthur Mutambara.

${ }^{6} \mathrm{SADC}$ is the Southern Africa Development Community.
} 
This is the accepted version of an article published by Cambridge in The Journal of Modern African Studies Vol. 53 No. 1, pp. 27-49, 2017. Published version available from: https://doi.org/10.1017/S0022278X14000640

Accepted version downloaded from SOAS Research Online: https://eprints.soas.ac.uk/26245/

Government of National Unity (GNU) in which Tsvangirai became prime minister and the then leader of the smaller MDC Arthur Mutambara became deputy prime minister. $^{7}$

The GNU period was one of relative stability. Much has been written about this 'transitional period', describing the fractured fortunes of the parties involved - in particular Tsvangirai's inability to say no to Mugabe, the degree to which the ZANU(PF) machine was able to subvert MDC ambitions, the frustrations of trying to make a government work with limited resources, and tensions within the MDC-T, particularly between Tsvangirai and Finance Minister Tendai Biti. ${ }^{8}$

A key danger of the GNU for the MDC parties was the extent to which it would weaken the polarisation that gave them their distinct identity and undermine existing mobilisation strategies. Tensions and the challenge of governing would certainly take their toll on the MDCs' ability to present a clear alternative, but the fact that the parties showed they could cooperate, even to a limited degree, also established a sense of consensus which further eroded the politics of polarisation. The best example of this was the creation of a new constitution, which the parties constructed together, and which was accepted in a referendum in early 2013 by $95 \%$ of those voting. ${ }^{9}$ The cross-party consensus on this key document which redefined the country's political settlement further consolidated the sense of unity within and beyond government.

\footnotetext{
${ }^{7}$ Mutambara was subsequently challenged by Welshman Ncube who became leader of the party (now MDC-N) although Mutambara remained deputy prime minister.

8 For example, see Masunungure \& Shumba 2012; Raftopoulos 2013; Chan \& Primorak 2013.

9 The turnout of 50 per cent was high by recent Zimbabwean standards.
} 
This is the accepted version of an article published by Cambridge in The Journal of Modern African Studies Vol. 53 No. 1, pp. 27-49, 2017. Published version available from: https://doi.org/10.1017/S0022278X14000640

Accepted version downloaded from SOAS Research Online: https://eprints.soas.ac.uk/26245/

The constitution included measures designed to make future elections free and fair, including reforms to the security services and state media - both of which operated in the interests of ZANU(PF) - and the establishment of a new independent electoral commission to oversee the compiling of the electoral roll and the voting process. ${ }^{10}$ When Mugabe announced the election date of 31 July, the SADC governments supported the MDCs' concerns that these reforms would not have time to become effective, and urged Mugabe to postpone the date. However, when Zimbabwe's constitutional court upheld Mugabe's preferred date, the opposition parties decided to go ahead, apparently assuming that they could still win.

The two MDCs went into the election separately. Both hoped to perform well in urban areas, Manicaland in the east and Matabeleland in the south-west. Many of the Shonaspeaking rural areas had been considered ZANU(PF) strongholds; however many had experienced high levels of violence in 2008, and the MDCs were confident that rural voters had also had enough of ZANU(PF). The MDC-N, led by Ndebele Welshman Ncube, expected to do well in Matabeleland.

\section{A BRIEF NOTE ON METHODOLOGY AND THE CONDUCT OF INTERVIEWS}

Before I turn to an analysis of the election, I want briefly to discuss the interview methodology. This research was conducted as part of a long-term project on Zimbabwe, and thus built on substantial networks and well-established levels of trust.

\footnotetext{
10 See gta.gov.zw [cited 4 March 2014].
} 
This is the accepted version of an article published by Cambridge in The Journal of Modern African Studies Vol. 53 No. 1, pp. 27-49, 2017. Published version available from: https://doi.org/10.1017/S0022278X14000640

Accepted version downloaded from SOAS Research Online: https://eprints.soas.ac.uk/26245/

It involved interviews with 69 people, carried out three months after the elections, in the urban areas of Harare, Bulawayo and their environs, and the rural areas of Matabeleland South and Mashonaland Central. ${ }^{11}$ Interviewees included party activists from both MDC parties and from ZANU(PF), as well as civil society and community activists, some of who maintained a more or less neutral stance, but many of whom were closely aligned with the MDCs. Some interviews were conducted one-to-one (many people preferred to do this so they did not have to express their views publicly) and others were in groups of between two and 15. All interviewees spoke off the record.

Interviewees were invited to tell the story of the elections, and left to define the key elements for themselves. This provided a subjective account of the elections, and I do not attempt in my analysis to explore the validity of what was said. The accounts provide perspectives on how people felt about the choices open to voters and my analysis focuses on what this reveals about their approach to the state.

Because these interviews took place three months after the elections, as the country was still digesting the outcome, much of the thinking expressed was under development: these were some of the first opportunities for grassroots activists to air and develop a verdict on what had happened. Interviews with MDC supporters were

\footnotetext{
11 These locations were chosen in order to capture differences in attitude between both urban/rural and Shona/Ndebele voters. Harare and Bulawayo have been MDC strongholds in the past, but Harare lost several key constituencies to ZANU(PF) in 2013. Mashonaland in the north of the country has consistently voted for ZANU(PF) and Matabeleland in the west voted overwhelmingly for the MDC parties in 2008, but saw a dramatic shift towards ZANU(PF) in 2013.
} 
This is the accepted version of an article published by Cambridge in The Journal of Modern African Studies Vol. 53 No. 1, pp. 27-49, 2017. Published version available from: https://doi.org/10.1017/S0022278X14000640

Accepted version downloaded from SOAS Research Online: https://eprints.soas.ac.uk/26245/

by far the most informative. Activists from both parties, facing a crushing electoral defeat, seemed to be in the mood to dissect the features of their failure, and in particular to explore how their relationships with the electorate had broken down during the GNU period. ZANU(PF) activists were far more complacent and understandably less introspective about the outcome. I have tried as much as possible to reflect the flavour as well as the content of these discussions, quoting at length, and including some of the exchanges within group interviews.

I began all interviews by asking, 'what happened in the elections?' Interviews with MDC supporters followed a pattern: first, people described the shock they had felt at the results; second, they began to detail accounts of electoral rigging such as policemen assisting voters, returning officers hiding ballot papers, or large numbers of people voting without ID. However, as the interviews progressed, people began to reflect more and more on the conduct of politicians in the elections, and the ways in which voters had responded to them. MDC activists revealed their sense of frustration at their own leaderships, and began to put together a coherent picture of why many voters had turned to Mugabe and ZANU(PF).

In cases where I was interviewing groups of MDC activists, the discussion frequently became intense, with members of the group heatedly debating the failings and inevitable downfall of their parties. People expressed disgust at the way they and the voters had been taken for granted, and many members of the groups angrily announced that they would leave the party. In many cases, interviewees also expressed ambivalent feelings about the electorate. There was understanding for the choices made by many voters, and activists were often quick to blame their own 
This is the accepted version of an article published by Cambridge in The Journal of Modern African Studies Vol. 53 No. 1, pp. 27-49, 2017. Published version available from: https://doi.org/10.1017/S0022278X14000640

Accepted version downloaded from SOAS Research Online: https://eprints.soas.ac.uk/26245/

parties for their loss of support. However interviewees also revealed their irritation at what they described as the gullibility of voters who believed ZANU(PF) policy promises, or the immaturity of voters who were persuaded by small gifts to support the ruling party. Ultimately, activists revealed sympathy for the attractions of ZANU(PF), as well as disgust at its use of manipulation.

\section{WHAT VOTERS THOUGHT IN 2013}

The activists I interviewed ranged over several factors that make a party electorally successful. Each was described as important to voters, although their relative weight varied according to class, whether they were urban or rural residents, and the region in which they lived. I have broken these down into three broad areas: violence and constraint; gifts and provision; and policies and values. These categories are not discrete - material factors, including gifts, the role of government as provider, and questions of land and fairness of distribution are closely tied up with ideas about what government is for and thus closely inform values. The material therefore is not just a question of calculation of personal interest, but part of an ideological approach to political settlement. The fear which underlay the choice of many voters might also be seen as settling over aspects of the material and ideological. Fear is bound up with physical and material security, both of which are echoed in questions of how the state provides for and protects citizens. For Zimbabweans in 2013, particularly important were questions of the authority of leadership that were offered by each party, something that was often implicitly underwritten by ideas of a powerful and even abusive state. I am not trying to suggest that Zimbabweans welcome the prospect of 
This is the accepted version of an article published by Cambridge in The Journal of Modern African Studies Vol. 53 No. 1, pp. 27-49, 2017. Published version available from: https://doi.org/10.1017/S0022278X14000640

Accepted version downloaded from SOAS Research Online: https://eprints.soas.ac.uk/26245/

an abusive state; but that the violence many had internalised since 2008 had become part of their sense of an inevitable relation to the state.

\section{(a) Violence and constraint}

Activists described three areas that can be construed as constraining voters: the fear of violence, the fear of loss, and exhaustion in the face of the determination of ZANU(PF). Violence was not explicit in these elections, but in many areas, the fear of it had been internalised and dominated people's approach to voting. This was strikingly the case in both ZANU(PF)'s rural strongholds in Mashonaland and in poor urban areas. In these areas, people do not like to talk about politics - it was difficult to get interviews, and people were usually only prepared to talk one-to-one, and in secret.

In interviews in Mashonaland Central, people highlighted the fear that meant that MDC supporters had to keep quiet. One NGO worker who works with rural farmers throughout the region said:

In the rural areas especially in the former commercial farms, anything associated with the MDC will land you in trouble - even talking [about the party] is promoting [it] and saying that you want our land repossessed... MDC supporters were given t-shirts but they could not put them on. I had one but didn't wear it. They were saying, we want peace, but people thought they could be lying to us - people remembered $2008 .^{12}$

\footnotetext{
12 NGO worker, Mashonaland Central, 14 November 2013
} 
This is the accepted version of an article published by Cambridge in The Journal of Modern African Studies Vol. 53 No. 1, pp. 27-49, 2017. Published version available from: https://doi.org/10.1017/S0022278X14000640

Accepted version downloaded from SOAS Research Online: https://eprints.soas.ac.uk/26245/

And a head teacher from the same region said:

This [election] was very peaceful. People were very relieved. But it was peaceful in the sense that people had memories of the last one, so they would go for ZANU(PF), they would have memories of the punishment they perceived they would be getting... In 2000 it was about 70 per cent in favour of the MDC. In 2007 things began to change when there was a lot of intimidation. It became a 50/50 situation. Then 2008 to now, it's in favour of ZANU(PF) because of that fear. If you would try to assemble people to a ZANU(PF) rally, they would go because they know the consequences of not going. But for an MDC rally, they don't go because they are frightened. ${ }^{13}$

This fear translated into voting behaviour, according to the head of an NGO in Mashonaland Central. He pointed out that people not only voted for ZANU(PF), but made sure that the right people knew they had done so:

What [ZANU(PF)] did in 2008 was intentional and it's still very clear in people's minds. They made it very peaceful [this time] but people feared the violence would come back... people were aware that if they voted MDC they might get back to 2008. A lot of people who said they can't write said that because they wanted people to see they had voted correctly [for ZANU(PF)]. ${ }^{14}$

Some urban areas experienced a similar story. In one group interview with traders in Bulawayo I struggled to get anyone to say anything at all. Only once I was able to talk

\footnotetext{
13 Head teacher, Mashonaland Central, 14 November 2013

14 NGO head, Mashonaland Central, 14 November 2013
} 
This is the accepted version of an article published by Cambridge in The Journal of Modern African Studies Vol. 53 No. 1, pp. 27-49, 2017. Published version available from: https://doi.org/10.1017/S0022278X14000640

Accepted version downloaded from SOAS Research Online: https://eprints.soas.ac.uk/26245/

to them separately did they begin to open up about their fear of talking politics in front of each other. None of these traders had voted: they felt it was safer to avoid the election altogether. ${ }^{15}$ Experiences in Harare were similar. One civil society activist who works in Mbare and Highfields, some of the city's most impoverished areas said:

The threat was in the minds of people. ZANU(PF) youths in hushed tones had implied that if you vote for the MDC we are going to repeat the 2008 drama. They didn't need to deploy their violence machinery. ${ }^{16}$

Alongside the threat of violence was the fear felt by many of the rural and urban poor about the threat to their livelihoods that would come about if they voted for the MDC parties. The ability of the urban poor to access market trading stands and permits, and to avoid harassment, is intimately wound up with their political affiliation. In some areas, having ZANU(PF) connections is essential to keeping your family alive, and anything that jeopardises that is to be avoided. Harare's Mbare, scene of the brutal Murambatsvina campaign where houses were bulldozed by the police in 2005 , is one such area.

Everywhere in Mbare there are vendors. They were allowed there by ZANU(PF) who said they must be allowed to make a living. ZANU has created the conditions for destitution and desperation and given them the protection of the law...They are acting like a saviour. The poor people, very ignorant people, these people believe in ZANU(PF)...They have problems but they cannot go against ZANU(PF). ZANU protects them. They need police protection. In

\footnotetext{
15 Interviews with traders, Bulawayo, DATE

16 Civil society leader, Harare, 4 November.
} 
This is the accepted version of an article published by Cambridge in The Journal of Modern African Studies Vol. 53 No. 1, pp. 27-49, 2017. Published version available from: https://doi.org/10.1017/S0022278X14000640

Accepted version downloaded from SOAS Research Online: https://eprints.soas.ac.uk/26245/

them there is no hope for a better life than this... They are supporting the government because it offers them a way to support themselves, a way of making a living. If they support the MDC they are victimised and evicted. ${ }^{17}$

The fear of losing livelihoods extends into the issue of land which is still controlled by the largely ZANU(PF)-loyal village headmen. Patronage networks in the rural areas make allegiance to the ruling party essential for survival. For this reason, the MDC came to be seen as a threat, as one group of activists discovered:

The ZANU message meant people were voting for ZANU to keep their farms. We were once nearly attacked as MDC activists by the community. The language that their leadership was using was that if the MDC would win, you will lose your farms. The traditional leaders said this. $^{18}$

For the opposition it was frustrating to see how the ZANU(PF) logic has seeped into people's sense of their ability to survive. 'ZANU(PF) creates a situation and then comes in as a saviour,' explained one MDC activist, while another said: 'This is a party that has survived by keeping people poor and insecure. ${ }^{19}$ A teacher who is an observer rather than a participant in party politics likened this to an abusive relationship.

17 Civil society leader, Harare, 4 November.

18 MDC-N activist, Bulawayo 9 November 2013

${ }^{19}$ MDC-T activist, Chitungwiza, 3 November; Trade union activist, Harare 5 November 2013 
This is the accepted version of an article published by Cambridge in The Journal of Modern African Studies Vol. 53 No. 1, pp. 27-49, 2017. Published version available from: https://doi.org/10.1017/S0022278X14000640

Accepted version downloaded from SOAS Research Online: https://eprints.soas.ac.uk/26245/

People are not employed. If you come as a saviour they love you. The government is like a demagogue, people are very emotional about that. You make them suffer and then you come with promises and people will believe you. They torture you and then offer to help you. Now people are thinking about their stomachs. Even me, if I was offered \$1,000 I would say that is what I want. ${ }^{20}$

In this environment, political engagement has become too expensive. Such an outlook can appear to amount to a giving up: if $\mathrm{ZANU}(\mathrm{PF})$ is determined to win at all costs, better to give them what they want so that you can get on with your life. A Bulawayo teacher expressed this view most coherently:

Slowly but surely people are starting to prioritise the issue of political stability. If they make the opposition win, there is likely to be war in this country. People chose peace, not violence... Since independence, ZANU has been winning elections. In 2002 people had hoped ZANU was going down the drain. In 2008 from what we saw, the MDC won, and they were rigged. This time I think people got tired and said, this guy is not prepared to relinquish power. $^{21}$

The factor of violence is an example of a tangible constraint on voters in 2013. As the Mashonaland teacher suggested, it has gradually over the years whittled down support for the MDC, making visible support for ZANU(PF) appear increasingly necessary for people's security and survival. It has driven many of the urban poor away from politics, as they prefer to keep their heads down and get on with making a living. Where violence once energised and bound political activists together, providing a

20 Teacher, township near Bulawayo, 9 November 2013

21 Teacher, township near Bulawayo, 9 November 2013 
This is the accepted version of an article published by Cambridge in The Journal of Modern African Studies Vol. 53 No. 1, pp. 27-49, 2017. Published version available from: https://doi.org/10.1017/S0022278X14000640

Accepted version downloaded from SOAS Research Online: https://eprints.soas.ac.uk/26245/

backbone for the MDC's support base, it now appears to have helped overcome polarisation by making allegiance to the opposition parties a hazardous and increasingly unthinkable option.

\section{(b) Gifts and provision}

A prominent issue in discussions about the election result was the material. This is unsurprising for a population which has suffered severe economic hardship in recent years. Formal sector jobs are rare (an estimated 90 per cent of people make a living through informal trade), most of the population struggles to access services like education and healthcare, the infrastructure in cities - roads, sewage, water and electricity - are highly unreliable, and a large majority struggle to meet basic needs such as decent housing and adequate food (Musunungure \& Ndapwadza-Chingwete 2012). The issue of material provision arose in three main ways: first, in the election strategies, second, in the policies and third, in the capacities of the main parties.

ZANU(PF)'s election programme focused on providing gifts to the electorate. ${ }^{22}$ Many commented on the impact this had, and compared it unfavourably with the more parsimonious approach of the MDC parties. In particular, ZANU(PF)'s arrival with gifts was noticed by people in Matabeleland who have felt neglected by the ruling party for many years, and who have consistently voted for opposition parties. Here are

\footnotetext{
22 Zamichya details the very different resources available to each party: the MDC had just \$100 for each council candidate, $\$ 1,400$ for each parliamentary candidate, and 300,000 t-shirts for the whole country (2013: 961), a tiny proportion of ZANU(PF)'s campaign resources (Tendi 2013: 963).
} 
This is the accepted version of an article published by Cambridge in The Journal of Modern African Studies Vol. 53 No. 1, pp. 27-49, 2017. Published version available from: https://doi.org/10.1017/S0022278X14000640

Accepted version downloaded from SOAS Research Online: https://eprints.soas.ac.uk/26245/

some of the typical comments people made on the giving of gifts during the election campaign:

During election time it was a free-for-all. Politicians gave out rice and promised [people] areas to build their houses. The appeal of ZANU(PF) was direct and immediate..$^{23}$

They bring food during campaign time. You can't get from the MDC and so people thought, I'm missing a lot supporting the MDC so I will move to that party. ${ }^{24}$

ZANU(PF) was giving everyone caps, t-shirts, Zambias and bandanas, and the opposition was giving to party members. I was angry that I didn't get anything. The MDC didn't give to all the people, they didn't recognise all the people. ${ }^{25}$

ZANU(PF) went with pots, caps, food. People said, we were given these things so we will support. Last time the MDC did the same and this time they did not. ${ }^{26}$

The giving of gifts was important on several levels. There was the recognition explicitly mentioned in one of the comments above - that the gifts exemplified. That a political candidate had bothered to court the voters was an indication of their worth. Moreover, the value of things even as small as a cap, a t-shirt or a kilo of maize, to

23 MDC-T activist, Bulawayo, 9 November.

${ }^{24}$ MDC-T activist, Matabeleland South, 10 November.

${ }^{25}$ A Zambia is a piece of cloth women wear over their skirts. Village headman, Matabeleland South, 10 November.

${ }^{26}$ Priest, township near Bulawayo, 12 November. 
This is the accepted version of an article published by Cambridge in The Journal of Modern African Studies Vol. 53 No. 1, pp. 27-49, 2017. Published version available from: https://doi.org/10.1017/S0022278X14000640

Accepted version downloaded from SOAS Research Online: https://eprints.soas.ac.uk/26245/

people who are very poor, is significant. Thus, ZANU(PF)'s gifts during the election campaign had both material and symbolic meaning.

But also, the giving of small gifts was seen as representative of a larger tendency towards the importance of material things to the main parties and this was reflected for voters in their policies. This is my second point about the material aspect of the campaign, and it deals with the resonance of each party's proposed programme. ${ }^{27}$ Many Zimbabweans argue that ZANU(PF)'s policies focused more explicitly and clearly on delivering economic wealth than did the MDCs'. ZANU(PF)'s key 'indigenisation and empowerment' policy is to transfer 51 per cent of all companies to black Zimbabweans. This policy followed up on land redistribution, from which many Zimbabweans have benefited, and offered attractive prospects in contrast to MDC policies which were seen as more abstract and difficult to grasp. As one ZANU(PF) activist remarked:

Zimbabweans are very excited at having their pieces of land. That is what made them $[\mathrm{ZANU}(\mathrm{PF})]$ win the hearts of people. ${ }^{28}$

Opposition activists agreed, as these comments from activists in Bulawayo and Harare show:

\footnotetext{
27 These accounts support Raftopoulos's argument about the importance of the new economic structures that have come to shape people's relationship with ZANU(PF) in recent years (2013). 28 ZANU(PF) activist, Bulawayo, 11 November.
} 
This is the accepted version of an article published by Cambridge in The Journal of Modern African Studies Vol. 53 No. 1, pp. 27-49, 2017. Published version available from: https://doi.org/10.1017/S0022278X14000640

Accepted version downloaded from SOAS Research Online: https://eprints.soas.ac.uk/26245/

I asked a man why did you vote for ZANU(PF)? He said, they brought food, community share ownership. This for them is development. The MDC[-N] talks devolution. ${ }^{29}$

People in Zimbabwe don't want just change, they want sustainable change that gives them bread and butter... The MDC[-T] dismissed [the] empowerment and indigenisation programme. [But] the 10 per cent delivers schools and clinics and roads. It's ZANU(PF) that is doing that and the MDC is talking about human rights and respect for the law. That's academic: it doesn't put bread on the table. ${ }^{30}$

Alongside the prospects of increased wealth was the fear of being left out. Many people spoke of the benefits of affiliation to ZANU(PF) and the ways in which they had previously been excluded from opportunities. This aspect had a particularly significant effect on middle-class voters. One Harare-based businessman said:

The problem for the MDC is that the middle class grew very well under the GNU. My brother did very well - he bought two houses. When he has a party for his kid he invites 500 people. He used to be a strong MDC man. Now he is ZANU(PF). He sees many opportunities from the indigenisation programme and being part of ZANU. ${ }^{31}$

To a degree, MDC activists felt that the electorate had been conned, but many also accepted that some of the effects were real, as comments by (first) a staunch MDC activist in Chitungwiza and (second) an MDC member and civil society activist in Bulawayo show:

\footnotetext{
${ }^{29}$ MDC-N activist Bulawayo, 9 November.

30 Civil society leader, Harare, 4 November.

31 Businessman, Harare, interviewed in Bulawayo, 9 November.
} 
This is the accepted version of an article published by Cambridge in The Journal of Modern African Studies Vol. 53 No. 1, pp. 27-49, 2017. Published version available from: https://doi.org/10.1017/S0022278X14000640

Accepted version downloaded from SOAS Research Online: https://eprints.soas.ac.uk/26245/

People who voted [for Mugabe] voted by their bellies not their heads... After the farm and company grabs people who had been left out see that others have benefited - now I can benefit. No one in the MDC has benefited so I need to join ZANU(PF)... People are fooled to think, I am going to be rich. ${ }^{32}$

ZANU(PF) met the needs of the people. They resettled farmers and they allowed prospectors to pan for gold freely and lots came... In parts of Matobo the shared ownership is really working for people. They have schools and clinics. They are becoming better off. These are not token changes, they are real..$^{33}$

This leads to the third aspect of the material element of the election: the ability of the parties to wield power effectively. It was apparent to many that only ZANU(PF) could deliver the material benefits they wanted, opening up larger problematic questions about power as access to resources. An exchange between two MDC activists highlights this:

The one who can carry that out is the one in power, the one with money. That is only ZANU(PF). ZANU is everywhere. For immediate solutions for people from any corner of Zimbabwe [they] would have to approach ZANU(PF).

\footnotetext{
32 MDC-T activists, Chitungwiza, 3 November.

33 Civil society activist, Bulawayo, 13 November.
} 
This is the accepted version of an article published by Cambridge in The Journal of Modern African Studies Vol. 53 No. 1, pp. 27-49, 2017. Published version available from: https://doi.org/10.1017/S0022278X14000640

Accepted version downloaded from SOAS Research Online: https://eprints.soas.ac.uk/26245/

In Bindura this ZANU guy was saying, I will sort out your roads. He gets on his phone and the caterpillars arrived during the meeting. He would say, you're hungry. He would phone and the tractors with maize would come. ${ }^{34}$

The enormous figure of Mugabe embodies the capacity of the ruling party. Even people who are very critical of him worried about what they might lose if Mugabe failed to win the presidency. Mugabe was variously described as 'a genius', 'British at heart... a man of his word' and 'very impressive... [able to] touch people'. ${ }^{35}$

Every politician is held up to Robert Mugabe. Mugabe listens very well, very critically, and he can make appropriate responses. ${ }^{36}$

In contrast, Tsvangirai's competence was questioned because of his failure to effect a coalition with the MDC-N, and because of the fighting within the MDC-T itself, particularly over the selection of election candidates. The party was described as 'poorly-organised and indisciplined'. ${ }^{37}$ Its failure to create and project a compelling and coherent set of policies was also put down to Tsvangirai's weakness, and the fact that his energies were directed towards a string of love affairs and paternity suits after the death of his wife in 2009. On Tsvangirai himself, people said:

\footnotetext{
34 Discussion between MDC-N activists, Bulawayo, 9 November.

35 NGO worker, Mashonaland Central, 14 November; Civil society leader, Harare, 4 November; Businessman, Harare, interviewed in Bulawayo, 9 November.

36 Civil society leader, Harare, 4 November.

37 Civil society leader, Bulawayo, 11 November.
} 
This is the accepted version of an article published by Cambridge in The Journal of Modern African Studies Vol. 53 No. 1, pp. 27-49, 2017. Published version available from: https://doi.org/10.1017/S0022278X14000640

Accepted version downloaded from SOAS Research Online: https://eprints.soas.ac.uk/26245/

He is not competent, he gives conflicting theories of the MDC... Soon there will be no difference between him and the president. ${ }^{38}$

He is a hero for bringing democracy but people don't trust him to lead the country. ${ }^{39}$

I would not want to vote for a president that sleeps around..$^{40}$

And on the MDC more broadly:

These $[\mathrm{MDC}]$ people were drifting away from the people. And they were imposing candidates that people didn't want. This worsened the situation. I think if people are disgruntled, they will go and vote otherwise. Some did. ${ }^{41}$

Morgan [Tsvangirai] and Welshman [Ncube] were supposed to reconcile and fight for the people of Zimbabwe but they went back to fight each other. ${ }^{42}$

Many were disillusioned by the inadequacies of the MDC in power. Corruption was an important factor - people observed that in office, the MDC was no different from ZANU(PF) - but alongside this was the perception that having the MDCs in power had not made any difference. This was particularly the case in Matabeleland where people talked about the MDC as though they had been in charge of the country. Three

\footnotetext{
38 Priest, township near Bulawayo, 12 November.

${ }^{39}$ NGO leader, Mashonaland Central, 14 November.

${ }^{40}$ Civil society leader, Harare, 4 November.

41 Trade union activist, Harare, 15 November.

42 MDC-N activist Bulawayo, 9 November.
} 
This is the accepted version of an article published by Cambridge in The Journal of Modern African Studies Vol. 53 No. 1, pp. 27-49, 2017. Published version available from: https://doi.org/10.1017/S0022278X14000640

Accepted version downloaded from SOAS Research Online: https://eprints.soas.ac.uk/26245/

comments - one from a ZANU(PF) activist and two from neutral community workers

- express this sentiment:

They thought the MDC would give them a chance for recognition. The MDC was scoring almost 100 per cent. But alas, after the GNU people in Matabeleland still realised nobody was listening. They were still being neglected. So better go back to the devil we know. ${ }^{43}$

Most people, once they have been disappointed in the GNU, they felt they were being left out... A lot of people felt, we have given you a chance, but it's still sliding down the scale so the best thing is to return that person who brought us independence and let him try again. ${ }^{44}$

What was promised, even by the MDC, was not delivered. Many people did not vote because they don't see any change. ${ }^{45}$

The MDC also suffered from the perception of its corruption in government. This was a double-edged problem. While many MDC MPs were criticised for their venality in government - they had 'become as bad as ZANU(PF) - they were also blamed for apparently refusing to take advantage of the access they did have. As one MDC-T activist put it: 'These MDC guys went into government and came out poor." ${ }^{46}$ The implication is that MDC MPs wasted opportunities to access resources which would

\footnotetext{
43 ZANU(PF) activist, Bulawayo, 11 November.

44 Teacher, township near Bulawayo, 9 November.

45 Priest, township near Bulawayo, 12 November.

46 MDC-T activist Matabeleland South, 10 November.
} 
This is the accepted version of an article published by Cambridge in The Journal of Modern African Studies Vol. 53 No. 1, pp. 27-49, 2017. Published version available from: https://doi.org/10.1017/S0022278X14000640

Accepted version downloaded from SOAS Research Online: https://eprints.soas.ac.uk/26245/

enable them to do the right thing. As one political activist put it, 'we have no problem where he gets the money from as long as he brings money to the people'. ${ }^{47}$

These conversations highlight the emphasis many Zimbabweans put on the willingness and capacity of government to provide them with things - from caps to jobs. The MDC parties' failure then was partly put down to their inability to understand the politics of provision to many Zimbabwean voters whose focus on patronage and consumption appear out of step with the MDCs' liberalism and focus on democracy and human rights. One MDC-T activist showed clearly how this idea of a state that provides continues to shape voters' expectations:

The MDC failed to understand the rural voter. He thinks if he votes for a councillor or an MP he can bring us things, bring maize, build clinics and drill boreholes... They see an MP, they see God. We have failed to teach the electorate how politics works. ${ }^{48}$

\section{(c) Policies and values}

Material issues were underwritten by policies and values. Here again ZANU(PF) presented a far more coherent and resonant account of itself than the opposition parties, in particular being able to convey the idea that they were best-positioned to represent Zimbabweans. The MDC parties, better at representing what they are

\footnotetext{
47 This man did not want to tell me which party he worked for, preferring to be described as a 'political activist', Matabeleland South, 10 November.

${ }^{48}$ MDC-T activist, Bulawayo, 9 November.
} 
This is the accepted version of an article published by Cambridge in The Journal of Modern African Studies Vol. 53 No. 1, pp. 27-49, 2017. Published version available from: https://doi.org/10.1017/S0022278X14000640

Accepted version downloaded from SOAS Research Online: https://eprints.soas.ac.uk/26245/

against rather than what they are for, have a weaker hold on their supporters than ZANU(PF), as pointed out by a ZANU(PF) activist:

At the formation of the MDC the ZCTU [Zimbabwe Congress of Trade Unions] was leading, but there were other groupings - the students' unions, the industrialists, the technocrats these had different agendas. But they came together with one agenda, the red card to remove Robert Mugabe from power. There was no clear answer to what came after. ${ }^{49}$

Several civil society observers provided a similar analysis, pointing out that once the polarisation between the parties had dissolved, the ephemeral nature of the MDC programme became more apparent:

People support the MDC as an alternative, rather than as an ideal political party. ${ }^{50}$

There is no ideological connection between the sympathisers and the MDC... The opposition offers nothing tangible or ideal. ${ }^{51}$

And MDC activists themselves were beginning to question the parties' priorities. The MDC-T ideology is rooted in human rights and democracy, values it says ZANU(PF) has transgressed, while the MDC-N has focused on devolution, attempting to encapsulate Ndebele desires for self-determination. These values, people point out, failed to ignite popular interest in 2013.

\footnotetext{
49 ZANU(PF) activist, Bulawayo, 11 November.

50 Agricultural advisor, Mashonaland Central, 14 November.

51 Civil society leader, Bulawayo, 11 November.
} 
This is the accepted version of an article published by Cambridge in The Journal of Modern African Studies Vol. 53 No. 1, pp. 27-49, 2017. Published version available from: https://doi.org/10.1017/S0022278X14000640

Accepted version downloaded from SOAS Research Online: https://eprints.soas.ac.uk/26245/

The MDC is talking about human rights and respect for the law. That's academic: it doesn't put bread on the table..$^{52}$

The people rejected [Welshman Ncube and his policy of devolution]. It is an elite concept. ${ }^{53}$

The MDC is from the people by the people. It is supported by everybody here. It is a democratic party and everybody needs democracy. They need democracy, but first they need food on their table. ${ }^{54}$

Also damaging was the MDC-T's perceived espousal of gay rights, frequently cited as a Western influence:

The Christian community thinks Tsvangirai can tolerate Satanism and homosexuality. ZANU capitalised on that. It is very important. If a president says yes yes to homosexuality that frightens a lot of people. The connection with the West destroyed Tsvangirai. ${ }^{55}$

The MDCs' ideologies were frequently described as alien, or as luxuries, while ZANU(PF)'s were felt to be a more essential part of Zimbabweanness. The ruling party's focus on race, land - the 'mother of African being' (Ndlovu-Gatsheni 2009) and liberation attracted many Zimbabweans. MDC supporters admitted that ZANU(PF)'s anti-colonial rhetoric and promises over land resonate with people:

\footnotetext{
52 Civil society leader, Harare, 4 November.

53 Civil society leader, Bulawayo, 8 November.

54 Political activist, Matabeleland South, 10 November.

55 Civil society leader, Harare, 4 November.
} 
This is the accepted version of an article published by Cambridge in The Journal of Modern African Studies Vol. 53 No. 1, pp. 27-49, 2017. Published version available from: https://doi.org/10.1017/S0022278X14000640

Accepted version downloaded from SOAS Research Online: https://eprints.soas.ac.uk/26245/

There are racial issues. There is skewed distribution of wealth... the racial divide is still very strong. You see it in industry. All whites are directors, not front-line staff. This is why the indigenisation and empowerment programme has resonance, even if it's a very stupid programme..$^{56}$

The land issue is very important to Zimbabweans. We all want to be farmers ... Mugabe's rhetoric on land and race really resonated with Zimbabweans. It means a lot to them. ${ }^{57}$

MDC supporters said that their party was unable to commit to these key issues because of their association with white farmers.

We were funded by white farmers so we had to run away from that issue [of land redistribution]. The pictures of those white farmers signing cheques was the downfall of the MDC. $^{58}$

Race and land are powerfully evoked in memories and myths of the liberation struggle which Mugabe has successfully embodied. The MDC in contrast, is often thought to have belittled this important historical moment, and again, its association with the white farmers and its Western supporters reinforces this perception. MDC loyalists and more neutral observers both emphasised this problem, as the following two comments show:

\footnotetext{
56 Trade union activist, Harare, 5 November.

57 Trade union activist, Harare, 15 November.

58 MDC-N supporter, Bulawayo, 9 November.
} 
This is the accepted version of an article published by Cambridge in The Journal of Modern African Studies Vol. 53 No. 1, pp. 27-49, 2017. Published version available from: https://doi.org/10.1017/S0022278X14000640

Accepted version downloaded from SOAS Research Online: https://eprints.soas.ac.uk/26245/

The MDC disassociated from the liberation struggle. They failed to form a war vets association. Mugabe talks about history and it's important to people. ${ }^{59}$

You would be surprised at the numbers that go to see the liberation fighters being buried. There is still an emotional attachment to the liberation struggle ... Look at the number of people who lost brothers and children, who don't know where their mother or father are. It's difficult to remove that emotional attachment. Whoever wants to be a leader must show appreciation for what happened in the liberation struggle. ${ }^{60}$

The MDCs, having once been part of the story of Zimbabwe, were now seen as foreign. This was tackled explicitly by many of those I interviewed, including by a group of MDC supporters in Bulawayo who were trying to explain their parties' collapse in Matabeleland:

These politicians read too many English books. What people want is not what the books say. If my kids are not well, I expect the MP to take them to hospital.

It doesn't appeal to a person in a rural area.

But if he raised the issue of hyenas attacking people in our areas, then they will say, here is a man who understands us.

The MDC was busy with the urban population, copying Obama, using facebook. But most people [in the rural areas] don't use facebook.

\footnotetext{
${ }^{59}$ MDC-T activist, Bulawayo, 9 November.

60 NGO leader, Mashonaland Central, 14 November.
} 
This is the accepted version of an article published by Cambridge in The Journal of Modern African Studies Vol. 53 No. 1, pp. 27-49, 2017. Published version available from: https://doi.org/10.1017/S0022278X14000640

Accepted version downloaded from SOAS Research Online: https://eprints.soas.ac.uk/26245/

I think both MDCs don't understand their own voters. If their voters ask for sadza, they bring tea. ZANU knows that people want farms. ${ }^{61}$

While the MDC language and priorities often grated with voters, ZANU(PF) was making explicit attempts to reconnect. A group of MDC supporters in Bulawayo explored the way in which the party wooed the voters:

ZANU managed to mend relationships.

They pretended.

No they mended.

Mugabe went everywhere - he was the most serious candidate, he was the most visible. ${ }^{62}$

And one man I spoke to described how the party's attempts met with a sense of relief and homecoming.

My uncle is a very strong MDC man. He was a war vet, spent 20 years in Zambia. He hates ZANU(PF) ... The MDC never came. The area is where [Vice President] Joice Mujuru is from. She came. She asked what were the issues. She saw the hospital which has no supplies or doctors, the bad roads, the lack of jobs. And she said, sorry, we have let you down. We will try to do better. And she gave them maize. My uncle saw a young boy who was giving out

\footnotetext{
${ }^{61}$ Sadza is Zimbabwe's national dish. Discussion between MDC activists, Bulawayo, 9 November.

62 Exchange between MDC activists, Bulawayo, 9 November.
} 
This is the accepted version of an article published by Cambridge in The Journal of Modern African Studies Vol. 53 No. 1, pp. 27-49, 2017. Published version available from: https://doi.org/10.1017/S0022278X14000640

Accepted version downloaded from SOAS Research Online: https://eprints.soas.ac.uk/26245/

MDC t-shirts being intimidated by a ZANU supporter. And a policeman came and stopped him. My uncle was so impressed. And he thought, maybe we can return to our liberation, maybe we can give them one more chance. So he voted ZANU(PF). ${ }^{63}$

Race, land and liberation are values that are important to many Zimbabweans, tied into the material through issues surrounding distribution, fairness and the role of the state, and contributing powerfully to their sense of identity. The opposition parties' values were viewed at best as luxuries, or worse as out of touch.

\section{CONCLUSION}

The evidence presented here suggests that Zimbabwe's period of transition saw a shift in voter allegiance away from the MDC vision of liberal politics, towards Mugabe's more assertively nationalistic one. The MDC parties were described as selfish, uncaring and detached, unsuccessful in government, and unable to deliver. Their values were out of reach, impractical, and failed to embody the essence of Zimbabwe. Their leaders, tarnished by incompetence, corruption or venality, had lost authority. Crucially, the parties' lack of clarity about what they stood for had become a liability; where once this had opened up opportunities for supporters to imagine an ideal party - often one that could embody Western success - now this ideal was dissipated or even viewed as alien.

\footnotetext{
63 Businessman, Harare, interviewed in Bulawayo, 9 November.
} 
This is the accepted version of an article published by Cambridge in The Journal of Modern African Studies Vol. 53 No. 1, pp. 27-49, 2017. Published version available from: https://doi.org/10.1017/S0022278X14000640

Accepted version downloaded from SOAS Research Online: https://eprints.soas.ac.uk/26245/

In contrast, voters were drawn to the more materially-focused agenda presented by Mugabe's party. ZANU(PF)'s ideas of a politics of provision, supported by its ability to access and use resources, and its resonant rhetoric on land and liberation seemed to meet Zimbabweans' needs, and 'win their hearts'. The material and ideological aspects of this election are closely entwined - land, for example, encompasses both. Being able to access resources is an important issue for Zimbabweans, partly because of their own need to survive and flourish, and partly too because of the way it embodies their expectation of government as a provider and carer - many looked for the candidate who gives caps to everyone in the community, the MP who attends funerals or takes your sick child to hospital, the government that ensures your region its share of access to land.

This tendency to conflate and balance material and ideational expectations of politicians is a feature of elections elsewhere in Africa. Nugent, for example, has discussed the significance of gift-giving, highlighting the relationship between gifts and moral authority. He argues that 'the distribution of banknotes or bags of rice goes far beyond being a purely material exchange. It demonstrates that the politician does recognize his/her local responsibilities' (2007: 257). And on a more diffuse level, the question of a party's successful representation of its followers, has been described by Randall as both the ability to respond to their demands and the ability to embody their characteristics (2007). ZANU(PF)'s success can be explained in terms of its ability to successfully conflate gift-giving with moral authority, and to convey the sense that it was able to represent voters in terms of its capacity to understand and meet demands, and to express a sense of the wider collective. 
This is the accepted version of an article published by Cambridge in The Journal of Modern African Studies Vol. 53 No. 1, pp. 27-49, 2017. Published version available from: https://doi.org/10.1017/S0022278X14000640

Accepted version downloaded from SOAS Research Online: https://eprints.soas.ac.uk/26245/

However, underlying this, was the recognition of ZANU(PF)'s stranglehold on resources that made alternatives unviable. While the party's projection of Zimbabwean identity contributed to its political authority, giving some voters the sense that they were 'coming home' to Mugabe, they remained aware of its history of violence and authoritarianism. Many people, in choosing the politics and state identity offered by ZANU(PF), also understood the compulsion they were under from the violent subtext of the party's message and methods.

Alexander and McGregor point out that Zimbabwe has often offered a 'poor fit' to broader Africanist literature on the state because its particular history entrenched 'ideas of legitimate statehood hinged centrally on law and expertise: [which] offered African avenues for imagining and demanding citizenship' (2013: 751). These ideas however, have been eroded by economic and political crisis which have been used by ZANU(PF) to entrench a patronage economy backed up with violence. Indeed citizens' perceptions of the state in Zimbabwe do now appear closer to Mbembe's depiction of postcolonial politics across much of the continent. States, he suggests, are viewed both as providers of protection and moral superiority, 'organizer[s] of public happiness' (31), and wielders of arbitrary violence, woven into the allocation of privileges. His suggestion of this as a complex relationship and a complex basis for the imaginary of the state resonates with current conceptions of state-society relations in Zimbabwe, in which attachments to a legal-bureaucratic state appear weakened.

2013 was an election that saw polarisation replaced by ambivalence. As the MDC melted away as a viable alternative government, many voters turned back to ZANU(PF), both with fear and resignation and with a sense of reconnection. One 
This is the accepted version of an article published by Cambridge in The Journal of Modern African Studies Vol. 53 No. 1, pp. 27-49, 2017. Published version available from: https://doi.org/10.1017/S0022278X14000640

Accepted version downloaded from SOAS Research Online: https://eprints.soas.ac.uk/26245/

might even call this a mixture of hatred and love. They did not feel neutral or indifferent to what party ruled them, or the kind of state they expected from it. Rather, Zimbabweans, in a moment of critical national introspection, appear to recognise that they have chosen a form of state that embodies the instrumentalism of violent prebendalism and patronage, and a welfare state that understands and embodies collective identity. It is a 'good' state and a 'bad' state.

\section{REFERENCES}

Alexander, Jocelyn \& JoAnn McGregor 2013. 'Introduction: politics, patronage and violence in Zimbabwe', Journal of Southern African Studies 39(4): 749-63

Bratton, Michael \& Nicolas Van de Walle 1997. Democratic Experiments in Africa: regime transitions in comparative perspective. Cambridge: Cambridge University Press.

Chan, Stephen \& Ranka Primorak, eds. 2013. Zimbabwe since the Unity Government. London: Routledge.

Erdmann, Gero 2007. 'The cleavage model, ethnicity and voter alignment in Africa: conceptual and methodological problems revisited', GIG Working Papers 63.

Gallagher, Julia 2013. 'Good state/Bad state: loss and longing in postcolonial Zimbabwe' in Ebenezer Obadare, ed. The Handbook of African Civil Society. New York: Sage.

Horowitz, Donald 1993. 'Democracy in divided societies' Journal of Democracy 4, 4: $18-38$

LeBas, Adrienne 2011. From Protest to Parties: party-building and democratization in Africa. Oxford: Oxford University Press. 
This is the accepted version of an article published by Cambridge in The Journal of Modern African Studies Vol. 53 No. 1, pp. 27-49, 2017. Published version available from: https://doi.org/10.1017/S0022278X14000640

Accepted version downloaded from SOAS Research Online: https://eprints.soas.ac.uk/26245/

LeBas, Adrienne 2014. 'The Perils of Power Sharing' Journal of Democracy 25, 2: 52-

66.

Lindberg, Stefan \& Minion Morrison 2008. 'Are African voters really ethnic or clientelistic? Survey evidence from Ghana', Political Science Quarterly 123

Mamdani, Mahmood 2008. 'Lessons of Zimbabwe', London Review of Books 30, 23: $17-21$

Masunungure E. V. \& J. M. Shumba, eds. 2012. Zimbabwe: mired in transition. Harare: Weaver Press.

Mbembe, Achille 2001. On the Postcolony. London: University of California Press.

McGregor, JoAnn 2013. 'Surveillance and the City: patronage, power-sharing and the politics of urban control in Zimbabwe' Journal of Southern African Studies 39, 4: 783-805.

Muzondidya, James 2009. 'From buoyancy to crisis, 1980-1997' in Brian Raftopoulos \& Alois Mlambo (eds) Becoming Zimbabwe: a history from the pre-colonial period to 2008. Harare: Weaver Press.

Ndlovu-Gatsheni, Sabelo 2009. 'Making sense of Mugabeism in local and global politics: "So Blair, keep your England and let me keep my Zimbabwe", Third World Quarterly 30, 6: 1139-58.

Nugent, Paul 2007. 'Banknotes and Symbolic Capital: Ghana's Elections under the Fourth Republic' in Matthias Basedau, Gero Erdmann \& Andreas Mehler, eds. Votes, Money and Violence: political parties and elections in sub-Saharan Africa. Uppsala: Nordiska Afrikainstitutet: 253-75.

Raftopoulos, Brian 2009. 'The crisis in Zimbabwe, 1998-2008' in Raftopoulos \& Alois Mlambo, eds. Becoming Zimbabwe: a history from the pre-colonial period to 2008. Harare Weaver Press: 201-32.

Raftopoulos, Brian, ed. 2013. The Hard Road to Reform: the politics of Zimbabwe's global political agreement. Harare: Weaver Press. 
This is the accepted version of an article published by Cambridge in The Journal of Modern African Studies Vol. 53 No. 1, pp. 27-49, 2017. Published version available from: https://doi.org/10.1017/S0022278X14000640

Accepted version downloaded from SOAS Research Online: https://eprints.soas.ac.uk/26245/

Raftopoulos, Brian 2013. 'The 2013 elections in Zimbabwe: the end of an era', Journal of Southern African Studies 39, 4: 971-88.

Randall, Vicky 2007. 'Political Parties in Africa and the Representation of Social Groups' in Matthias Basedau, Gero Erdmann \& Andreas Mehler, eds. Votes, Money and Violence: political parties and elections in sub-Saharan Africa. Uppsala: Nordiska Afrikainstitutet: 82-104.

Sachikonye, Lloyd 2011. When a State turns on its Citizens: institutionalized violence and political culture. Harare: Weaver Press.

Tendi, Blessing-Miles (2010) Making History in Mugabe's Zimbabwe: politics, intellectuals and the media. Oxford: Peter Lang.

Tendi, Blessing-Miles 2013. 'Robert Mugabe's 2013 Presidential Election Campaign' Journal of Southern African Studies 39, 4: 963-70.

Zamchiya, Phillan 2013. ‘The MDC-T’s (Un) Seeing Eye in Zimbabwe's 2013 Harmonised Elections: a technical knockout' Journal of Southern African Studies 39, 4: 95562.

\section{NoTES}

